\title{
The Representation of The Tri Hita Karana Ecosophy in The Awig-awig (Customary Law) Text of Tenganan Pegringsingan Village: Critical Ecolinguistics Perspective
}

\author{
I Gede Astawa \\ Denpasar Academy of Tourism, Bali, Indonesia \\ Made Budiarsa \\ Udayana University, Bali, Indonesia \\ I Wayan Simpen \\ Udayana University, Bali, Indonesia
}

\begin{abstract}
The awig-awig (Customary Law) of Tenganan Pegringsingan Village has existed since $11^{\text {th }}$ century before the Tri Hita Karana ecosophy was initiated in Bali; however, this awig-awig was able to preserve the environment, in terms of natural environment (palemahan), social environment (pawongan), and spiritual environment (parhyangan). The present study aims at investigating evaluations and assessment of the THK ecosophy employed in the awig-awig text of Tenganan Pegringsingan village. The research aspires to reveal the value of relationship of human with the natural, social, and spiritual environments. The data of the research were taken from the written text of the awig-awig. The collected data were analysed using critical ecolinguistics approach, referring to evaluation theory proposed by Stibbe (2015) and appraisal Theory by Martin and White (2005). The results showed that the awig-awig text reveals positive, ambivalent, and negative evaluations. The positive evaluations are in a line with the THK ecosophy; the ambivalent evaluation contradicts between positive and negative evaluations; whereas, the negative one contradicts to the ecosophy.
\end{abstract}

Index Terms - ecosophy, Tri Hita Karana, awig-awig, critical ecolinguistics

\section{INTRODUCTION}

The presence of ecolinguistics studies is to dissect stories that surround humans. Ecolinguistics regards to ecology and language; however, both are in separate area of life (Stibbe, 2015). Sapir (in Fill \& Mühlhäusler, 2001, p. 14) states that the relationship between language and environment specifically reflects the physical characteristics of the environment, the way of life, culture, the complexity of ideas, and live hood in certain environments. Furthermore, Haugen (in Fill and Mühshäusler, 2001, p. 57) states that the language environment is the language user community that characterizes the environment. In line with Haugen's opinion above, Bang and Døør (1996, p. 1) assert that language cannot be separated from its environment; language does not have meanings without the environment. Each linguistic description is also a description of the language environment. Bang and Døør's opinions were also reinforced by van Lier $(2004$, p. 48$)$ who stated that in addition to dealing with the physical environment, language in depth also relates to the social and cultural environment in which humans live.

Language influences how humans think about the world. A lot of things that happen around us are considered a success in improving economic development; however, it is not realized that the development is ecologically destructive. For example, the rapid development of tourism in Bali contributes a very significant foreign exchange to the country; however, this progress encourages the exploitation of nature, cultural distortion, and commercialization of holy places that should be kept away from the ideology of capitalism.

As a savior of ecological damage, Bali has an "ecosophy" (philosophy of ecological harmony) that regulates human harmony with the three environmental dimensions, namely the spiritual, social and natural environment. This ecological philosophy is known as Tri Hita Karana (THK). The existence of the THK which is practiced by Hindus in Bali aims to harmonize human relations to the Almighty God, other humans, and nature so that human life is happy and prosperous (Wiana, 2007, p. 5-6; Peter and W. Wardana, 2013, p. 52). These three relationships are dialectical, depending on one another.

One of the ways to restore the balance of human relations to God, to others, and to nature is to implement the concepts of the THK into the awig-awig. The awig-awig in Bali is believed to be able to regulate people's lives so that the three environments that are the source of human happiness and prosperity can be carried out harmoniously. The 
awig-awig contains a set of rules as a guideline for behavior in a society that is accompanied by sanctions that are carried out firmly and real (Dharmika, 1992).

One of the awig-awigs that has existed since $11^{\text {th }}$ century is the awig-awig belongs to Tenganan Pegringsingan Village. During the composing of the awig-awig, the THK concept has not been initiated in Bali. This becomes an interesting phenomenon to be studied with regard to how the text producer through the linguistic features used has a dimension to maintain and preserve the spiritual, social, and natural environments before the concept of $T H K$ was introduced.

\section{THEORETICAL FRAMEWORK}

This present study applied two theories, namely evaluation theory and appraisal theory. Both theories were used to analyse the representation of THK ecosophy in the Awig-awig text of Tenganan Pegringsinga Village.

\section{A. Evaluation Theory}

Stibbe (2015, p. 84) defines evaluation as stories in people's mind; whether an area of life is considered good or bad. In line with Stibbe's definition above, Bednarek (2007) defines evaluation as a reference to language expressions from the opinions of speakers or writers with a number of semantic dimensions and parameters. Language evaluation can relate to the assessment of entities or propositions, such as good or bad, important or unimportant, comprehensive or incomprehensive, possible or impossible, sincere or insincere, expected or unexpected. Whereas, Hunston and Thompson (2005) define evaluation as a term of expression of attitude or the position of speaker/writer's views or feelings about the form or proposition being discussed.

\section{B. Appraisal Theory}

In recent years, the appraisal theory has been widely used in different genres to study whether and how slightly different appraisal methods are used in them (Xiaqing, 2016, p. 559). In ecolinguistics, evaluation can be investigated by using appraisal theory. Appraisal theory deals with how the writer/speaker agrees and disagrees, is enthusiastic and dislikes, appreciates and criticizes, and how to position the reader/listener to do the same thing (Martin and White, 2005; Sinar, 2008). Furthermore, Stibbe (2015, p. 84) states that appraisal patterns are clusters of linguistic features which come together to represent an area of life as good or bad. This study is intended to investigate evaluations and assessments of human relations to natural, social, and spiritual environments employed in the awig-awig text belongs to Tenganan Pegringsingan Village.

\section{RESEARCH METHOD}

This study applied a qualitative method. Data collection method used was documentation method. The data taken in this study were in the forms of lexicons, grammatical constructions, and other linguistic features used in the awig-awig text belongs to Tenganan Pegringingan Village which are related to the representation of human relations to the Almighty God, other humans, and nature. Furthermore, these data were analyzed using evaluation theory developed by Stibbe (2015) and appraisal theory developed by Martin and White (2005). The evaluations revealed then were judged according to the ecosophy of $T H K$.

\section{RESULTS AND DisCUSSIONS}

\section{A. The Representation of Human Relation to Nature}

Nature is seen as valuable to itself because there is life in it, by itself humans are seen as an inseparable part and depend entirely on nature (Keraf, 2014, p. 89). At the biological level, humans cannot live without water, air, and food provided by nature; economically, humans depend entirely on nature, on ecosystems, on everything provided by nature around their homes; in terms of culture, humans cannot live as cultured beings and are as they are without nature. Human culture depends entirely on the surrounding environment (Keraf, 2014, p. 91). Therefore, humans cannot be seen as the center of the universe system, as is the view of anthropocentrism. Representation of human relations to nature revealed in the awig-awig text of Tenganan Pegringsingan Village can be observed from the following quotations.

(1) tan kawasa wong désa ika sinalih tunggal anyandayang, angadol carik, abian, muah pakarangan

'the villagers are not allowed to pawn and sell rice fields, gardens, and yards'

ADATP-7

Implicitly, the phrase anyandayang muah angadol carik abian pekarangan 'pawning or selling rice fields, gardens and yards' in quote (1) is considered as a negative appraisal. In addition to being controlled by other people, the land that is pawned or sold can potentially change the function and damage the ecological environment of Tenganan Pegringsingan Village. This has implications for environmental damage if the land use is contrary to the awig-awig owned, as well as the economic empowerment of the community by establishing modern accommodation for tourists, beside changing the natural village appearance, it will have an impact ecologically detrimental to the survival of tradition and culture. 
Until the present time, lands in Tenganan Pegringsingan Village area still remain the property of the villagers that are used for the benefit of the community collectively. The use of paddy fields, gardens or plantation is not individuallyspatially but is used together. Therefore, the prohibition on selling or pawning land is a positive effort to prevent the ecological damage. Thus, the prohibition made by the text producer has a positive cultural evaluation "prevention is good", is an appraisal pattern that is acceptable with the language system, while the contradictory form "prevention is bad" will not be acceptable with the language system.

Lands owned by Tenganan Pegringsingan villagers were inherited by the ancestors, intended for the next generation, so that mortgaging or selling land is prohibited through the approved awig awig. If assessed by the ecosophy determined, the cultural evaluation "prevention is good" is in accordance with the value of THK, in terms of protecting the environment for the survival and welfare of Tenganan Pegringsingan Village community.

The same treatment was also addressed to migrants in Tenganan Pegingsingan Village, as shown by the lingual unit in the following quotation.

(2) wongé mangəndok ring pabumian Tenganan Pegringsingan, tlasing pada tan kawasa matuku gumi, muah manyanda carik, abian ring palasan Tenganan Pegringsingan

'the people migrating to Tenganan Pegringsingan area are really not allowed to buy and pawn rice fields or gardens in Tenganan Pegringsingan territory'

ADATP-15

Prohibition against outsiders who buy or pawn the land owned by Tenganan Pegringsingan villagers is closely related to preventive efforts so that the people of Tenganan Pegringsingan do not sell or pawn the land of their own. By forbidding newcomers from buying or pawning paddy fields or gardens, it is implicitly considered as a preventive action against the sale or pledge of rice fields or gardens. This condition has a positive cultural evaluation "prevention is good". Preventing residents' land in Tenganan Pegringsingan Village from being owned by outsiders is very important for the survival and environmental sustainability of the existence of Tenganan Pegringsingan Village.

(3) yan ana amurug angərəbah kayu muah jaka, wənang kang amurug kadanda

'If there is one violating; cutting down trees and palms, the violator worth fining'

ADATP-14

Martin and White (2005) state that many linguistic features that can evaluate the area of life both positively and negatively which are called "appraising items." The expressions tan kawasa 'not allowed or prohibited', amurug 'violate', and kadanda 'fined' explicitly reveal negative patterns of appraisal items. The grammatical structure in lingual ... ngarzbah jaka kari mabiluluk ... 'cutting down the palm trees that are still fruitful' is an appraisal item, which is negatively depicted "a threat x" (cutting down palm trees threatening ecological sustainability). Every living creature, including plants, has the right to live and humans must keep it so that the plants can benefit humans themselves and preserve the environment. Thus, the evaluation "cutting down trees are not good" is the reality that the palm tree has a very important function for the people of Tenganan Pegringsingan, especially fruiting palm trees that can produce tuak 'palm wine obtained by tapping inflorescences of the palms' for offerings in various rituals. Thus, the existence of palm trees is very important to be preserved by the local community. Therefore, the evaluation "cutting down trees are not good" contradicts with the positive evaluation "greening is good". While maintaining the preservation of palm trees in Tenganan Pegringsingan forest area, the culture of tapping palm trees to get the palm wine will be preserved. In addition, the function of preserving the palm trees is to green the local village area which is surrounded by hills and prevents landslides.

(4) ...tan kawasa malolumbaran ring abian muah ring carik, sawawongkon Tenganan Pegringsingan...

'it is not allowed to release animals in the garden or in the rice field in Tenganan Pegringsingan area'

ADATP-51

The lexicon malalumbaran 'letting animals roam wildly' in quote (4) has the potential to create environmental damage. Releasing wild animals can damage yards or gardens and pollute the environment. This is a negative evaluation "unbending pets is not good". But on the one hand, this evaluation is still problematic because it separates animals from their original ecosystems and confines, anchors, or puts them in the possession of animal rights as part of the ecosystem. This kind of pet discourse is called ambivalent discourse (Stibbe, 2015), which is a beneficial on the one hand, but destructive on the other hand. Confining, anchoring, or staring at a pet has a positive evaluation, namely that the environment is not damaged by these pets. But on the one hand, this has a negative evaluation of preventing animals' freedom to live in their natural habitats. However, for the people of Tenganan Pegringsingan Village, the animals that escape their cages have a greater tendency to damage the environment than beneficial factors they bring. Thus, the violations committed by the citizens if ngalumbar 'letting pets roam' will be kapratingkah 'convicted' by the village. The lexicon kapratingkah has a negative evaluation "punishment is not good". Therefore, releasing pets is greatly avoided by the people of Tenganan Pegringsingan in other not to get sanctions from the customary village.

\section{B. Representation of Human Relations with Other Human Beings}

Representation of human relations to other human beings in the ecosophy of $T H K$ is intended to create a safe and peaceful social life. Humans as social beings cannot live without others. Gare in Sttibe (2015, p. 8) calls it human ecology, namely human interaction with other humans. The arrangement of the social environment is intended for humanity to live in mutual service in accordance with swadharma 'obligations' respectively (Wiana, 2015, p. 23). 
According to Maria and Rupa (2007, p. 106), the relationship between humans in Tenganan PegringsinganVillage is called "sukerta tata pawongan". This dimension emphasizes the relationship of behavior in the family, interfamily, banjar 'sub village', and up to customary villages. Behavioral ethics is intended to have equality of rights and obligations in front of customary rules if they become krama adat 'cutomary village members. Furthermore, the importance of principal of reciprocity is also emphasized - the principle of giving in the hope of receiving it later. The existence of the social relations of Tenganan Pegringsingan Village community is also inseparable from the principles of saguluk, sagilik, salunglung sabayantaka, paras-paros sarpanaya, 'unite, respect each other's opinions, remind each other, love each other, and help each other'. This principle frames the harmony of social relations in Tenganan Pegringsingan Village which is still well preserved until now. Local indigenous peoples continue to realize the Tatwamasi philosophy (I am you, you are me) and the teachings of Yadnya 'holy offering to the Almighty God' become the basis of the life of indigenous village communities who prioritize shared interests by aligning personal interests in relation to the interests of society. Individual obligations are perceived as a call to the interests of living in togetherness, so that they appear to prioritize obligations rather than their rights. Examples of representation of human relations with other human beings can be seen from the following quotations.

(5) ...yan ana wong désa ika sinalih tunggal madruwé səntana katinggalin olih roramaniya, ... yaniya madum tatinggalan, tka wonang tkaning kacucuné paling wayah, istri kakung polih jomutan.

'If there are the villagers who have offspring that their parents have passed away, if they divide the inheritance, it is appropriate until the oldest grandchildren, both men and women, get a share

ADATP-18

Explicitly, the lingual unit in quote (5) above has a positive evaluation "justice is good". The awig-awig, which has been applied in Tenganan Pegringsingan Village since ancient times, has acknowledged gender equality. Rights and obligations between men and women are treated equally as long as they adhere to the agreed upon customary village rules.

(6) ...wong Désa Tenganan Pegringsingan yaniya cucaka, tan kawasa iya milot masangkəpan ring Balé Agung.

'people from Tenganan Pegringsingan Village, if they are disabled, they are not permitted to attend customary village meetings in the Bale Agung 'customary meeting hall'

ADATP-29

The lingual unit in quotation (6) represents that people who are not allowed to attend a customary meeting in the Balé Agung implicitly means that they do not have the status as customary members in the village. This is a negative evaluation "injustice is not good". People with disabilities are treated unfairly. Naturally, they are God's creatures who must be treated the same as those who have normal physical conditions. This condition is not in line with the ecosophy of THK, which teaches human to maintain harmony with other humans. This is also not in line with the teaching of Tat Twam Asi 'I am you and you are me ', so this needs to be challenged because it contributes to damaging the social environment.

(7) //...yan wongé sinalih tunggal, yan iya ngerangkatang wong kaksikang, pada tan kawasa, yaniya mamurug, wanang iya kadanda ...//

'anyone, if marrying a person who is subject to an exclusion sentence is absolutely prohibited; if one violates, he/she should be fined'

ADATP-40

The phrase wong kasikang 'ostracized person' in quote (7) is considered as a negative appraisal. The status of "wong kasikang" is a sanction received by a villager who is considered to have committed a serious offense. Marrying someone who is subject to "exclusion" sentence is categorized as having a big mistake, as shown in lingual units ... yan, ngarangkatang wong kaksikang, pada tan kawasa, ... "if marrying a person who is ostracized is strictly prohibited. The prohibition on marrying excommunicated person is problematic because there are indications of breaking someone's love which is an essential right of every human being. Punishing someone for marrying someone who is set aside from society is a negative cultural evaluation "breaking someone's love is not good". Every human being has the right to determine and choose the life partner he/she loves.

(8) //... tan kawasa bəlas makurənan, wiwah yan ana amurug sinalih tunggal, wənang iya kakésahang saking Desa Tenganan, ...//

'prohibited from divorcing; and if there is anyone who violates, it should be expelled from Tenganan Pegringsingan'

ADATP-49a

The lingual unit in quote (8) is a negative appraisal. Text producers in this case strongly oppose divorce. This is explicitly stated in the clause in quote (8) above. Divorce does need to be avoided because it has a negative cultural evaluation. This ban on divorce is a preventive measure for divorce for married couples. Implicitly, not divorce means a family is united. A partner who is harmonious and loyal to each other has a positive cultural evaluation "being united is good". However, on the one hand, the positive cultural evaluation "being united is good" to be problematic because it contradicts those who have household conflicts which should be the best way out is divorce. Although in a cultural evaluation "divorce is good" is unacceptable; however, for couples who consider divorce to be the best way to deal with household conflicts, then the evaluation "divorce is good" is acceptable. Therefore, good or bad evaluations of divorce must be viewed from two perspectives in the sense that if divorce will create a worse problem, the divorce has a 
negative cultural evaluation. Whereas, if the divorce is a better resolution of a conflict from an unhappy marriage, divorce has a positive evaluation.

\section{The Representation of Human Relation to Spiritual Environment}

The people of Tenganan Pegringsingan Village are Hindus of Indra sect. In daily life, the community remains concentrated in the three basic frameworks as a way of life, namely tatwa 'religious philosophy', susila 'ethics', and upakara 'ritual'. These three life guidelines present the awareness of the people of Tenganan Pegringsingan Village to create a harmonious relationship with the Creator of the universe, so that happiness and prosperity can be achieved. In this study, the evaluation of the relationship between humans and God was analyzed through appraisal items used in the awig-awig text. The evaluation revealed in the text, with its linguistic features, whether it describes something well or not, needs to be supported or challenged. Evaluation of human relations to the Almighty God can be examined from the following quotes.

(9) //...tatkalaning wong désa ika sinalih tunggal ngawéntonang pujakerti ring Désa Tenganan Pegringsingan ring sasih kalmia, tka wənang sapalasan pakarangan Tigasana kasalarin antuk wong désané ring Tenganan Pegringsingan,...//

'when anyone in the village is holding a worship in Tenganan Pegringsingan Village in the fifth month, it is appropriate for the Tigasana Village area to be donated with salaran (a kind of compulsory contribution which is usually in the form of crops) by Tenganan Pegringsingan villagers'

ADATP-13

The lexicon pujakérti 'worship' in quotation (9) is a devoted form of human to the Almighty God for creating the bhuana agung 'macrocosm' and the bhuana alit 'microcosm'. Thus, the pujakérti is a positive appraisal item. In the cognition of the Tenganan Pegringsingan Village community, worshiping God is an expression of gratitude for all the gifts of God. The Almighty God has created nature with all its contents for the life of all living things. Therefore, the quote above is a positive cultural evaluation "devotion to the almighty god is good". It corresponds to the ecosophy of creating a harmonious human relationship with the Creator of the universe through sincere sacrifice.

(10) //...kang né mangdok sasorohan makarya saluiré, wenang kang mangdok pakaryan, wenang iya anyarengin sapuja caruné ring Pandé, sanangken sasih kalima manut trap kadi saban//

'migrants as workers, for example, the immigrant must attend all traditional/religious ceremonies in Banjar Pande every fifth month in accordance with the applicable traditional rules'

ADATP-22

The quote (10) above is the reality of increasing devotion to God which is not only done by the indigenous people of Tenganan Pegringsingan Village, but also by the immigrants who live in Banjar Pande 'name of sub village. Implicitly, the lingual unit ... anyarengin sapuja caruné ring Pandé 'attending all the traditional ceremonies in Banjar Pandé is a positive cultural evaluation "devotion to the Almighty God is good". Attending traditional ceremonies is a manifestation of the sacred sacrifice to the Almighty God. Conducting traditional ceremonies is a way to make relations to the Almighty God, as the aim of the ecosophy of $T H K$ is to maintain a harmonious relationship with God in order to obtain happiness and prosperity for the life of mankind.

(11) /lyan ana wong désa ika sinalih tunggal mengambil misan, kahangén somah, ...tan wenang anyungsung kayangan ring Tenganan Pegringsingan...//

ADATP-16

'If there is anyone who takes the cousin as a wife or husband, the villager is prohibited from worshiping the shrines in Tenganan Pegringsingan ...'

The prohibition of conducting worships in holy places (temples) as a consequence of marriage with a cousin is certainly not acceptable from the perspective of ecosophy. The clause in quote (11) tan wenang anyungsung kayangan 'prohibited to worship in the temples' is a negative evaluation "forbidding people to worship is not good". Relations to the Almighty God should be formed from harmonizing relationships with others. Wiana (2015, p. 55) states that the Hindu worship system in Bali is an implementation of the concept of life based on the THK. The worship of God for Hindus also serves to organize the social system so that the social system can become a dynamic and productive medium. Productive in this case is interpreted as a social system that is expected to foster balanced spiritual and material values needed to build qualified human beings. Thus, in order to maintain the social environment, the prohibition on citizens to worship in holy places in Tenganan Pegringsingan should be considered from the aspect of humanity, since it is a personal relationship between humans and God.

\section{CONCLUSIONS}

The present study showed that the awig-awig text belongs to Tenganan Pegringsingan Village reveals evaluation that was then judged with the ecosophy used in this study, with the findings as follows (1) the awig-awig has beneficial; (2) ambivalent; and (3) destructive evaluations. The beneficial evaluation corresponds to the ecosophy determined in this study; the ambivalent evaluation consists of two evaluation namely beneficial in one hand; however, destructive in the other hand. Whereas, the destructive evaluation contradicts with the ecosophy used in this study. In critical ecolinguistics perspective, the beneficial evaluation needs to promoted, and the negative one needs to be resisted; 
however, the ambivalent one needs to be considered deeply in which the positive aspect need to be preserved, whereas the problematic one needs to be replaced with more beneficial alternatives.

\section{ACKNOWLEDGEMENTS}

I would like to express my great thanks to Arran Stibbe, Professor of Ecological Linguistics, University of Gloucestershire, for sending me some articles related to ecolinguistics study from perspective "the stories we live by".

\section{REFERENCES}

[1] Bang, J. and Døør, J. (2001). Ecology, Ethics \& Communication, Dialectical Ecolinguistics: Edited by Anna Vibeke Lind $\varnothing$ and Jeppe Bundsgaard, (53-84), University of Odense, Denmark.

[2] Bednarek, Monika. (2007). "Local Grammar and Register Variation: Explorations in Broadsheet and Tabloid Newspaper Discourse" (article) (serial online) [cited 2017 July 16] available from: http://ejournals.org.uk/ELR/article/2007/1.

[3] Dharmika, I. A. (1992). "Awig-awig Desa Adat Tenganan Pegringsingan dan Kelestarian Lingkungan : Sebuah Kajian Tentang Tradisi dan Perubahan" (thesis) (serial online), [cited 2017 Oct. 9]. Available from: www.lontar.ui.ac.id/opac/themes/libri2/detail.jsp?id=81933.

[4] Fill, A. dan P. Muhlhausler (eds). (2001). The ecolinguistic Reader: Language, Ecology and Environment. London: Continuum.

[5] Hunston, Susan \& Geoff Thompson. (2000). Evaluation in text: Authorial Stance and the construction of Discourse. Oxford: Oxford University Press.

[6] Li, Xiaqing. (2016). "An Attitudinal Analysis of English Song Discourse from the Perspective of Appraisal Theory" (article) (serial online), [cited 2018 Nov. 25]. Available from: DOI: http://dx.doi.org/10.17507/jltr.0703.17.

[7] Maria, Siti dan I Wayan Rupa. (2007). Monografi Desa Adat Tenganan Pegringsingan Kabupaten Karangasem Provinsi Bali. Jakarta: Departemen Kebudayaan da Pariwisata Direktorak Jenderal Nilai Budaya Seni dan Film, Direktorat Kepercayaan Terhadap Tuhan Yang Maha Esa.

[8] Peters, Jan Hendrik and Wisnu Wardana. (2013). Tri Hita Karana The Spirit of Bali. Jakarta: PT Gramedia.

[9] Sapir, Edward. (1912). Language and Environment. In: Alwin Fill Muhlhsudler, editors. The Ecolinguistics Reader: Language, Ecology and Environment. New York: Continuum. p13 - 23.

[10] Sinar, Tengku Silvana. (2006). Bahasa dalam Konteks Sosial: Pendekatan Linguistik Sistemik Fungsional terhadap Tata Bahasa dan Wacana. Medan: Pascasarjana Unimed.

[11] Stibbe, Arran. (2015). Ecolinguistics: Language, ecology and the story we live by. London and New York: Routledge.

[12] van Lier, Leo. (2004). The Ecology and Semiotics of Language Learning: A Sociocultural Perspective. New York: Kluwer Academic Publishers.

[13] Wiana, Ketut. (2007). Tri Hita Karana Menurut Konsep Hindu. Surabaya: Paramita.

I Gede Astawa was born in Tabanan, Bali, Indonesia. He is a lecturer in English Department at Denpasar Academy of Tourism, Bali, Indonesia. He obtained his Master Degree in Applied Linguistics (Language Teaching) in 2013 from Warmadewa University, Bali, Indonesia. He is currently a candidate doctorate in Linguistics at Udayana University and his main research is focused on ecolinguistics

Made Budiarsa is a Professor in Linguistics at Udayana University, Bali, Indonesia. He received his Master in Linguistics from Sydney University in 1988 and his Doctorate in Linguistics from Gajah Mada University, Jogyakarta, Indonesia in 2006. His research interests include a wide range of topics related to linguistics, especially sociolinguistics. He has supervised many theses and doctorate dissertations. He has participated in numerous national and international conferences and has written a lot of books and articles.

I Wayan Simpen is a Professor in Linguistics at Udayana University, Denpasar, Bali, Indonesia. He obtained his Master in Linguistics from Indonesia University, Jakarta, Indonesia in 1995 and his Doctorate in Linguistics from Udayana University in 2008. $\mathrm{He}$ has been a supervisor for numerous theses and doctorate dissertations. His research interests are ethnolinguistics and ecolinguistics. He has published many articles and book and actively participated in national and international conference and academic workshops. 